\title{
Nonstructural Carbohydrates in Roots of Gambel Oak Sprouts Following Herbicide Treatment
}

\author{
DAVID M. ENGLE AND CHARLES D. BONHAM
}

\begin{abstract}
Total nonstructural carbohydrate (TNC) concentrations in roots of Gambel oak sprouts as affected by herbicide applications were studied. TNC content varied significantly with changes in phenological stage and herbicide treatment. The storage cycle in sprout roots was found to differ considerably from that previously reported for roots of mature Gambel oak. Data from this study suggested that hormone-type herbicide applications should be made prior to the full leaf stage for maximum effectiveness. Roots of untreated oak sprouts in low densities contained significantly lower levels of TNC's compared to roots in high densities. No herbicide treatment reduced root TNC levels either 1 year following initial treatment or subsequent to second-year repeat applications. On the other hand, several herbicide treatments caused significant increases in root TNC's as compared with controls.

Effective control of Gambel oak (Quercus gambelii) on foothill ranges in Colorado, Utah, New Mexico, and Arizona can increase livestock and wildlife production and enhance the value of ranges as watersheds. However, past

Authors are graduate research assistant, Range Science Department, Colorado State University, presently assistant professor, Animal Science Department, South Dakota State University, Brookings, South Dakota 57007; and professor, Range Science Department, Colorado State University, Fort Collins, Colorado 80523.

This study was conducted at the San Juan Basin Research Center and is Contribution No. 2491 of the Colorado State University Experiment Station. The authors wish to thank Lawrence Bartel for his assistance in data collection and other phases of the study.

Manuscript received April 19, 1979.
\end{abstract}

treatments of many Gambel-oak-dominated ranges ] been essentially ineffective because prolific sprouting $f$ roots and basal stems results in the oak regaining domini in a few years. Basic knowledge about carbohydrate sto cycles in Gambel oak sprouts is needed to deter whether a relationship exists between carbohydrate sto patterns in roots and the effectiveness of hormoneherbicides in producing root kills. Then, measures of bohydrate storage levels in roots might be used to eval the potential for sprouting in plants treated with herbic

Moser (1977) suggested that an understanding of relationship of carbohydrate and herbicide translocati necessary for the effective use of herbicides. For exan phenoxy-type herbicides and picloram are both mobi the phloem and therefore are affected by carbohyc translocation. Thus, properly timed application will co pond with downard assimilate translocation so that $\mathrm{n}$ mum herbicide concentration will occur in the undergrc parts where effective plant damage will occur (Muzik 1! Bóo and Pettit (1975) stated that full leaf stage was c used for sand shin oak (Quercus havardii) as an indicato timing of systemic herbicide applications since net d ward translocation of photosynthate was usually occus at this stage. Marquiss (1969) stated that herbicides sh 
not be applied to Gambel oak prior to the full leaf stage, which he found to be the low period in carbohydrate storage in the roots of mature oak.

Trlica (1977) reviewed studies that related regrowth following a dormant period or defoliation to levels of stored carbohydrates in the plant. He found that the rate of regrowth was less for plants with lower carbohyd rate reserve levels. Berg and Plumb (1972) reported that plants were most susceptible to damage from phenoxy herbicides when carbohydrate reserves were lowest near the end of the spring flush of growth. They also found that there was a direct relationship between carbohyd rate reserve levels in roots or crowns of woody plants and the sprouting and regrowth potential.

The objectives of this study were to determine total nonstructural carbohydrate (TNC) concentrations in roots of Gambel oak sprouts in relation to major phenological events and to monitor the response of TNC concentrations in roots of sprouts following treatments with several herbicides.

\section{Materials and Methods}

The study was conducted at the San Juan Basin Research Center near Hesperus, Colorado, at an elevation of $2,316 \mathrm{~m}$. Average annual precipitation is $48 \mathrm{~cm}$, which is normally low from May through the first half of July. The soil is a fine sandy loam with an effective rooting depth of $152 \mathrm{~cm}$ or more and the vegetation is dominated by clumps of Gambel oak.

The study area was mechanically treated in 1975 with a roller chopper and oak sprouting was vigorous following the treatment. In June, 1976, 0.2 ha $(45 \times 45 \mathrm{~m})$ plots were treated at a rate of 1.40 , 1.12 and $0.56 \mathrm{~kg}$ a.e./ ha with the potassium salt of picloram (4-amino-3,5,6-trichloropicolinic acid), at 3.36 and $1.68 \mathrm{~kg}$ a.e./ha with the ethylene glycol butyl ether ester of triclopyr ${ }^{1}(3,5,6-$ trichloro-2-pyridyloxyacetic acid), and at 3.36 and $1.68 \mathrm{~kg}$ a.e./ ha with the triethylamine salt of triclopyr. Another treatment with the potassium salt of picloram formulated as $5 \%$ active ingredient (a.i.) pellets was applied to the soil. A single herbicide was applied to each plot except for the light rate treatments of the foliar-applied herbicides which were applied in two successive years to separate plots. Liquid herbicides were applied using a mist blower with water at a volume of 94 liters/ha. The pelleted herbicide was applied with a "whirlybird" spreader.

Gambel oak was in the full leaf stage both years when treated with the liquid herbicides. In 1976, spraying was conducted on all plots between July 23 and July 30. In 1977, all spray applications were applied on July 6 . The picloram pellets were applied August 9 , 1976.

Root samples were collected in 1977 from nine herbicide treatments plus a control at five phenological stages of growth and at two densities of oak sprouts. This resulted in a three factor experiment arranged in a completely randomized design with 20 treatment plots. The five stages of oak sprout phenology were: quiescence immediately prior to initiation of spring new growth (May 24), full leaf stage (June 27), rapid regrowth in late summer (July 25), end of rapid regrowth when new leaves were full size (September 2), and subsequent to leaf fall (October 8). These phenological stages were judged throughout the growing season of 1977 on control plots (Table 1). Two levels of relative oak sprout densities, low and high, were included as the third factor. These densities were determined in 1976, prior to initial herbicide treatments. Two plots of each treatment and the control, one plot with the highest and one with the lowest density of live oak sprout stems, were chosen to obtain data.

Stems from two oak plants were randomly selected on each sampling date and then excavated to a depth of about $30 \mathrm{~cm}$ to

'For experimental use only, not registered by the Environmental Protection Agency for use on rangeland.
Table 1. Phenological development of Gambel oak sprouts during the 1977 growing season.

\begin{tabular}{ll}
\hline $\begin{array}{l}\text { September } 1976 \text { to } \\
\text { May, 1977* }\end{array}$ & Sprouts quiescent. \\
May 28, 1977 & $\begin{array}{l}\text { Buds were enlarging on almost all sprouts with } \\
\text { new green growth visible. }\end{array}$
\end{tabular}

June 13, 1977

Leaves were approximately $3 / 4$ full size.

June $27,1977 *$

Leaves on sprouts were fully expanded

July $25,1977^{*}$

Stem elongation or rapid regrowth had begun to occur on all sprouts.

August 23, 1977

Stem elongation had ended on most sprouts, and new leaves were approximately $1 / 2$ full size.

September 2, 1977* Regrowth period had ended, with full expansion of new leaves.

October $8,1977^{*} \quad$ Few leaves remaining on sprouts.

* Carbohydrate root reserves sampled at these stages of development.

obtain root materials. Roots and rhizomes smaller than $1.0 \mathrm{~cm}$ diameter were cut into 5 to $10 \mathrm{~cm}$ sections. These were oven-dried at $65^{\circ} \mathrm{C}$ for a minimum of 48 hours and ground to pass through a 40-mesh screen for laboratory analysis. Extraction and determination of TNC's was made using procedures described previously by Trlica et al. (1977).

All data were subjected to analysis of variance. When significant F-values were found, Duncan's multiple range test was used to separate significant ( $P \leq 0.05$ ) differences among means.

\section{Results and Discussion}

\section{Carbohydrate Storage Cycle in Gambel Oak Sprouts}

A study of carbohydrate storage levels in roots of mature Gambel oak by Marquiss (1969) showed a spring drawdown of carbohydrate reserves that continued until the full leaf stage was reached. In this study, TNC's in roots of oak sprouts probably had a drawdown of shorter duration during spring growth and roots began accumulating TNC's before the full leaf stage was reached (Fig. 1). Although it appeared that there was no drawdown of reserves during spring growth, reserves probably declined after the first sampling date and then began restoration before the full leaf stage was reached. Sampling intermediate dates probably would substantiate this. Bóo and Pettit (1975) found a depletion cycle in roots of sand shin oak where TNC's in roots were depleted after leaf expansion began and reserves began accumulating when leaves were one-third to one-half size.

A definite period of carbohydrate drawdown in roots of oak sprouts occurred after the full leaf stage (Fig. 1). This period occurred during the late summer regrowth stage. Marquiss (1969) noted a period of low carbohydrate storage occurred in mature oak during late August. He suggested that this drawdown was caused by regrowth following summer rains after the spring drought.

Although no new growth occurred in late summer in sand shin oak, Bóo and Pettit (1975) found that late summer rains were also instrumental in initiating new aboveground growth from shallow rhizomes. Root carbohydrates were utilized for this regrowth and decreased TNC concentrations in the roots. It appeared from the present study that this stage of shoot elongation in Gambel oak sprouts was similar to the initial spring growth period since root TNC's began accumulating before shoot elongation and leaf expansion were completed. 


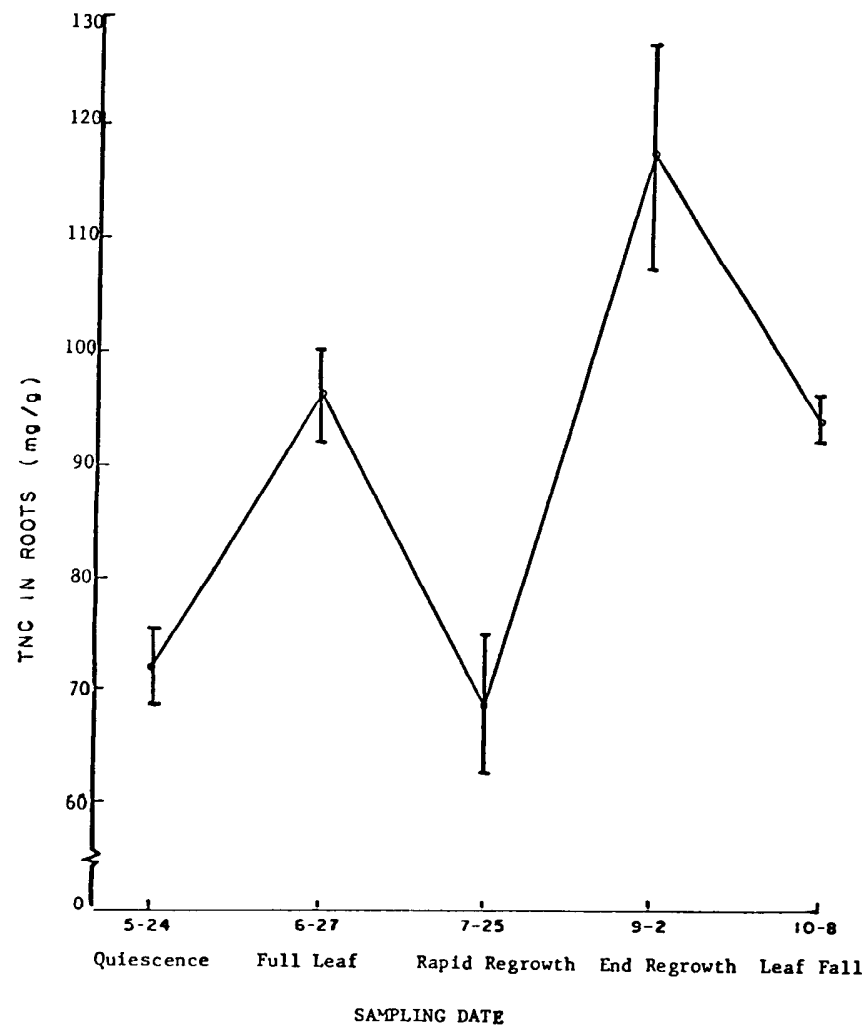

Fig. 1. Concentration of total nonstructural carbohydrates (TNC) in roots of Gambel oak sprouts for the 1977 growing season two years following mechanical treatment.

The fall regrowth period ended by September 2 and root TNC concentrations were at a season high, which would normally be expected before plants enter the dormant season (Trlica 1977). However, root reserves declined from September to the October 8 sampling date when most leaves had fallen. Since a rapid decline in TNC levels for this period is atypical for woody species, plausible explanations for this decrease are: (1) use of TNC's for root growth during this period, and (2) mature leaves acting as carbohydrate sinks.

Data from this study suggest that herbicide applications to oak sprouts should be made sometime before the full leaf stage is reached. Herbicides applied to sprouts in July, or
Table 2. Average total nonstructural carbohydrates (TNC) $(\mathrm{mg} / \mathrm{g})$ in roots of Gambel oak sprouts at two densities and five sampling dates.

\begin{tabular}{lllllll}
\hline \hline & \multicolumn{7}{c}{ Sampling Date } & & \\
\cline { 2 - 5 } Density & May 24 & Jun 27 & Jul 25 & Sep 2 & Oct 8 & Mean \\
\hline Low & $73.2 \mathrm{a}^{1}$ & $91.6 \mathrm{a}$ & $59.3 \mathrm{a}$ & $100.8 \mathrm{a}$ & $93.1 \mathrm{a}$ & $83.6 \mathrm{a}$ \\
High & $70.4 \mathrm{a}$ & $100.9 \mathrm{a}$ & $77.2 \mathrm{~b}$ & $133.8 \mathrm{~b}$ & $95.0 \mathrm{a}$ & $95.5 \mathrm{~b}$ \\
\hline
\end{tabular}

'Means in the same column followed by the same letter are not significantly different $(P \leq 0.05)$

after the full leaf stage, would coincide with an upward translocation of carbohydrates and herbicidal damage would probably be largely restricted to phytotoxic effects of aboveground tissues. Herbicides could also be applied to oak sprouts in late August before the end of fall regrowth to correspond with downward translocation of systemic herbicides. However, wax accumulations on the existing mature leaves might cause leaves to be less penetrable by herbicides compared with the first period of root reserve recharge.

Significant differences in root TNC concentrations occurred between low and high densities of oak sprouts when TNC values from control plots were separately subjected to analysis of variance. Average seasonal TNC concentrations in roots of low density oak sprouts were significantly lower $(83.6 \mathrm{mg} / \mathrm{g})$ than in roots of oak sprouts in the high density plots $(95.5 \mathrm{mg} / \mathrm{g}$ ) (Table 2). Also, a significant interaction effect was detected between densities and sampling dates. Root concentrations of TNC's were significantly lower for plants in the low density plots during rapid regrowth in late summer (July 25) and at the end of the regrowth period (September 2). The significantly lower levels of TNC's in roots of low density oak sprouts during active growth may have resulted from greater utilization of stored carbohydrates in the production of new sprouts and photosynthetic tissue.

\section{Herbicide Effects on Root Reserves}

Herbicide applications did not cause a significant reduction in TNC's but did result in significant increases in the season average TNC's for some treated plants over those of control plants (Table 3). The second-year repeat applications of three herbicide treatments also did not reduce root TNC levels (Table 4). In fact, seasonal mean TNC levels of roots in one of these three treatments were significantly

Table 3. Average total nonstructural carbohydrates (TNC)(mg/g) in roots of Gambel oak sprouts on five sampling dates in 1977 with nine herbicide treatments and two densities of oak sprouts.

\begin{tabular}{|c|c|c|c|c|c|c|c|c|c|c|c|c|c|}
\hline \multirow[b]{3}{*}{ Treatment } & \multirow{3}{*}{$\begin{array}{l}\text { Rate } \\
\text { (kg/ha) }\end{array}$} & \multirow{3}{*}{$\begin{array}{l}\text { Years } \\
\text { Applied }\end{array}$} & \multicolumn{11}{|c|}{ Sampling Date } \\
\hline & & & \multicolumn{2}{|c|}{ May 24} & \multicolumn{2}{|c|}{ Jun 27} & \multicolumn{2}{|c|}{ Jul 25} & \multicolumn{2}{|c|}{ Sep 2} & \multicolumn{2}{|c|}{ Oct 8} & \multirow[b]{2}{*}{ Mean } \\
\hline & & & $\mathrm{L}^{1}$ & $\mathrm{H}^{1}$ & $\mathrm{~L}$ & $\mathrm{H}$ & $\mathbf{L}$ & $\mathbf{H}$ & $\mathbf{L}$ & $\mathbf{H}$ & $\mathrm{L}$ & $\mathbf{H}$ & \\
\hline Picloram (K salt) & 1.40 & 1976 & $77.8 c^{3}$ & $94.4 b$ & 73.6de & $68.0 \mathrm{~d}$ & $76.4 \mathrm{c}$ & $85.8 \mathrm{abc}$ & $113.8 \mathrm{~b}$ & $98.3 \mathrm{~d}$ & $100.5 \mathrm{e}$ & $105.7 \mathrm{~b}$ & $89.4 d$ \\
\hline Picloram (K salt) & 1.12 & 1976 & $77.4 c$ & $86.2 c$ & $87.2 \mathrm{c}$ & $96.8 b$ & $79.0 \mathrm{c}$ & $90.4 \mathrm{a}$ & 90.4de & $100.0 \mathrm{~cd}$ & $108.3 \mathrm{~cd}$ & $107.8 \mathrm{~b}$ & $92.4 \mathrm{bcd}$ \\
\hline Picloram (K salt) & 0.56 & 1976,19772 & $100.8 \mathrm{a}$ & $89.6 \mathrm{bc}$ & $91.3 c$ & $100.0 \mathrm{ab}$ & $87.0 \mathrm{~b}$ & $91.2 \mathrm{a}$ & $106.8 \mathrm{c}$ & 107. Ibc & $109.8 \mathrm{~cd}$ & $103.8 \mathrm{~b}$ & $98.7 \mathrm{ab}$ \\
\hline Picloram ( $5 \%$ pellets) & 1.68 & 1976 & $99.9 \mathrm{a}$ & $104.6 \mathrm{a}$ & $79.0 \mathrm{~d}$ & $104.0 \mathrm{a}$ & $82.8 \mathrm{bc}$ & $82.8 \mathrm{bcd}$ & $96.6 d$ & $89.6 \mathrm{e}$ & $121.0 \mathrm{~b}$ & $109.8 \mathrm{~b}$ & 97.abc \\
\hline Triclopyr (amine salt) & 3.36 & 1976 & $78.4 \mathrm{c}$ & $84.4 \mathrm{c}$ & $111.6 \mathrm{a}$ & $97.0 \mathrm{ab}$ & $69.9 \mathrm{~d}$ & $78.0 \mathrm{~d}$ & $132.5 \mathrm{a}$ & $103.6 \mathrm{~cd}$ & $132.3 \mathrm{a}$ & $109.8 \mathrm{~b}$ & $99.8 \mathrm{a}$ \\
\hline Triclopyr (amine salt) & 1.68 & 1976,19772 & $89.4 b$ & $90.2 \mathrm{bc}$ & $79.0 \mathrm{~d}$ & $76.8 \mathrm{c}$ & $98.2 \mathrm{a}$ & $77.7 \mathrm{~d}$ & $90.8 \mathrm{de}$ & $106.1 \mathrm{bc}$ & $113.8 \mathrm{c}$ & $124.2 \mathrm{a}$ & $94.6 \mathrm{abcd}$ \\
\hline Triclopyr (ester) & 3.36 & 1976 & $86.6 \mathrm{~b}$ & $88.8 \mathrm{bc}$ & $68.8 \mathrm{e}$ & $95.0 \mathrm{~b}$ & $87.7 b$ & $80.3 \mathrm{~cd}$ & $119.0 \mathrm{~b}$ & $103.6 \mathrm{~cd}$ & $100.1 \mathrm{e}$ & $110.4 b$ & $94.0 \mathrm{abcd}$ \\
\hline Triclopyr (ester) & 1.68 & 1976 & $72.8 \mathrm{c}$ & $64.5 \mathrm{~d}$ & $104.8 \mathrm{~b}$ & $82.0 \mathrm{c}$ & $88.4 b$ & $80.8 \mathrm{~cd}$ & $105.2 \mathrm{c}$ & $100.6 \mathrm{~cd}$ & $100.5 \mathrm{e}$ & $90.9 c$ & $89.0 \mathrm{~d}$ \\
\hline Triclopyr (ester) & 1.68 & $1976,1977^{2}$ & $72.8^{4}$ & $64.5^{4}$ & $104.8^{4}$ & $82.0^{4}$ & $86.4 b$ & $78.0 \mathrm{~d}$ & 107.1c & $110.6 \mathrm{~b}$ & 104.6de & $91.8 \mathrm{c}$ & $90.3 \mathrm{~cd}$ \\
\hline Control & - & - & $73.2 \mathrm{c}$ & $70.4 \mathrm{~d}$ & $91.6 \mathrm{c}$ & $100.9 \mathrm{ab}$ & $59.3 \mathrm{e}$ & $77.2 \mathrm{~d}$ & $100.8 \mathrm{~cd}$ & $133.8 \mathrm{a}$ & 93.1f & $95.0 \mathrm{c}$ & $89.5 \mathrm{~d}$ \\
\hline
\end{tabular}

$\mathrm{I} L=$ low density; $\mathrm{H}=$ high density.

2The second-year repeat herbicide treatment was applied July 6, 1977.

${ }^{3}$ Means in the same column followed by the same letter are not significantly different $(P \leq 0.05)$

${ }^{4}$ Samples for these dates incorporated in previously listed treatment. 
Table 4. Average total nonstructural carbohydrates (TNC)(mg/g) in roots of Gambel oak sprouts on five sampling dates in 1977 as affected by second-year herbicide repeat applications applied on July 6, 1977.

\begin{tabular}{|c|c|c|c|c|c|c|c|}
\hline \multirow[b]{2}{*}{ Treatment } & \multirow{2}{*}{$\begin{array}{c}\text { Rate } \\
(\mathrm{kg} / \mathrm{ha})\end{array}$} & \multicolumn{5}{|c|}{ Sampling Date } & \multirow[b]{2}{*}{ Mean } \\
\hline & & May 24 & Jun 27 & Jul 25 & Sep 2 & Oct 8 & \\
\hline Picloram (K salt) & 0.56 & $95.2 \mathrm{a}^{1}$ & $95.6 \mathrm{a}$ & $89.1 \mathrm{a}$ & $107.0 \mathrm{~b}$ & $106.8 \mathrm{~b}$ & $98.7 \mathrm{a}$ \\
\hline Triclopyr (amine salt) & 1.68 & $89.8 \mathrm{a}$ & $77.9 \mathrm{~b}$ & $88.0 \mathrm{a}$ & $98.4 \mathrm{c}$ & $119.0 \mathrm{a}$ & $94.6 \mathrm{ab}$ \\
\hline Triclopyr (ester) & 1.68 & $68.6 \mathrm{~b}$ & $93.4 \mathrm{a}$ & $82.2 \mathrm{a}$ & $108.8 \mathrm{~b}$ & $98.2 \mathrm{c}$ & $90.3 b$ \\
\hline Control & - & $71.8 \mathrm{~b}$ & $96.2 \mathrm{a}$ & $68.2 b$ & $117.3 \mathrm{a}$ & $94.0 \mathrm{c}$ & $89.5 b$ \\
\hline
\end{tabular}

IMeans in the same column followed by the same letter are not significantly different $(P \leq 0.05)$.

higher than in roots of the control treatment at the end of the 1977 growing season, only 3 months following treatment.

Treatments of oak sprouts with hormone-type herbicides at the full leaf stage reduce the vigor and amount of top growth (Engle 1978). As a probable consequence of reduced top growth and stem kill, TNC levels were not decreased but in some instances were even significantly increased when compared to the control treatment. A similar phenomenon was found by Willard and McKell (1978) in snowberry (Symphoricarpus oreophilus), where partial defoliation of snowbcry increased plant vigor. It appeared that in snowberry partial defoliation reduced net photosynthate use for maintaining old growth and producing seed allowing for more storage of photosynthate.

Applications of the foliar-applied herbicides were timed to coincide with periods of high TNC storage levels in roots such that herbicide effects were mainly phytotoxic with little translocation of the herbicide and, therefore, little root kill. Phytotoxic effects caused severe defoliations but were of little consequence in causing plant death or reducing TNC levels in the roots. TNC storage levels in roots of herbicidetreated plants were possibly higher also because of lesser amounts of new sprouts drawing upon these reserves.

The main effect of density on TNC's in roots (Table 3 ) was not found to be different between roots of low and high oak sprout densities. However, differences were detected between phenological stages when considering all treatments. Implications of these results are more easily identified by examination of interactions that were tested.

The effects on TNC's of the second-year repeat applications of three herbicides (Table 4) exemplified the significant herbicide by phenological stage interaction. During the rapid regrowth in late summer (July 25 ) which followed the repeated herbicide application, herbicide-treated plants contained higher levels of TNC in the roots than controls. However, by the time regrowth had ended (September 2), roots of control plants contained higher TNC's than roots of other treatments. The high TNC levels in herbicide-treated plants on July 25 were probably the result of reduced maintenance requirements of top growth. However, on September 2, TNC levels in herbicide treated plants were possibly significantly lower as a result of demands for carbohydrate in producing new photosynthetic tissue. By the end of the growing season treated plants were higher in root TNC levels for two treatments, the $0.56 \mathrm{~kg} / \mathrm{ha}$ rate of piclo$\mathrm{ram}$ and the $1.68 \mathrm{~kg} /$ ha rate of the triclopyr amine salt, and not different from the control in one treatment, the 1.68 $\mathrm{kg} /$ ha rate of triclopyr ester. As in the case of the single-year applications, this would suggest that reductions in carbohydrate requirements for maintenance of old growth or the production of new sprouts would allow for greater TNC storage in the roots of treated plants.
The significant interaction of herbicide with phenological stage with sprout density suggested that herbicide effects on root TNC levels were not the same for all phenological stages and densities. However, this does not have any practical value since on October 8 there were no herbicide treatments on plots of either high or low density, with root TNC levels lower than the control (Table 3). On the contrary, roots of oak sprouts in at least several herbicide treatments exhibited significantly greater TNC concentrations for both sprout densities on this date. Therefore, although the pattern of the TNC storage cycle in the herbicide-treated plants differed significantly from the control with respect to phenological stage and density, these differences were not evident by the end of the growing season in 1977 .

Since TNC levels in roots of herbicide treated plants were not reduced, a practical implication is seen. Berg and Plumb (1972) stated that there was a relationship between carbohydrate reserve levels and the sprouting potential of woody plants with tops removed by chemicals or other methods. It is probable that the herbicide treatments in this study have not reduced the sprouting potential but only delayed sprouting. It should be noted, however, that had the spray applications been made at the proper phenological stage these results might be markedly altered.

\section{Conclusions}

TNC levels in roots of oak sprouts two growing seasons following mechanical treatment varied significantly with changes in phenological stage. This cycle differed considerably from that reported by Marquiss (1966) for mature oak. It is believed that foliar applications of hormonal herbicides on Gambel oak sprouts should be made sometime prior to full leaf stage for maximum translocation of herbicides to the roots. Treatment of oak sprouts with hormone-type herbicides at the full-leaf stage when herbicide effects were mainly phytotoxic did not reduce TNC levels in roots of treated plants, possibly as a result of reduced demand for carbohydrate reserves by aboveground growth. Oak sprouts treated with herbicides at full-leaf stage probably have sufficient levels of reserve carbohydrate to support continued sprouting.

\section{Literature Cited}

Berg, A.R., and T.R. Plumb. 1972. Bud activiation for regrowth. p. 279286. In: Wildland shrubs-their biology and utilization. U.S. Dep. Agr. Forest Serv. General Tech. Rep. INT-1.

Bóo, R.M., and R.D. Pettit. 1975. Carbohydrate reserves in roots of sand shin oak in West Texas. J. Range Manage. 28: 469-472.

Engle, D.M. 1978. Root carbohydrate reserves and herbicidal control of Gambel oak sprouts. Ph.D. Thesis, Colorado State Univ., Fort Collins. $71 \mathrm{p}$.

Marquiss, R.W. 1969. Studies on Gambel oak at the San Juan Basin Station. Colorado Agr. Exp. Sta. PR 69-38. 2 p. 
Moser, L.E. 1977. Carbohydrate translocation in range plants. p. 47-71. In: Sosebee, R.E. (ed.) Rangeland Plant Physiology. Range Science Series No. 4. Soc. Range Mange., Denver, Colo.

Muzik, T.J. 1970. Weed Biology and Control. McGraw-Hill Book Co., New York. 273 p.

Trlica, M.J. 1977. Distribution and utilization of carbohydrate reserves in range plants. p. 73-96. In: Sosebee, R.E. (ed.) Rangeland Plant Physiol- ogy. Range Science Series No. 4. Soc. Range Manage., Denver, Colo. Trlica, M.J., M. Buwai, and J.W. Menke. 1977. Effects of rest following defoliations on the recovery of several range species. J. Range Manage. 30: 21-27.

Willard, E.E., and C.M. McKell. 1978. Sprouting and carbohydrate reserves of two wildland shrubs following partial defoliation. J. Range Manage. 31: 141-145. 